фреймів $\epsilon$ гнучкою й узгодженою 3 психологічними концепціями пам'яті та експериментальними психофізіологічними даними.

\title{
Література:
}

1. Загальноєвропейські рекомендації з мовної освіти: вивчення, викладання, оцінювання / наук. ред. С.Ю. Ніколаєва. К: Ленвіт, 2003. $273 \mathrm{c}$.

2. Пентилюк М., Нікітіна О., Горошкіна О. Концепція когнітивної методики навчання української мови. Дивослово. 2004. № 8. С. 5-9.

DOI https://doi.org/10.30525/978-9934-26-114-5-62

\section{ФОРМУВАННЯ ГОТОВНОСТІ МАГІСТРІВ-ФІЛОЛОГІВ ДО НАУКОВО-ДОСЛІДНИЦЬКОЇ ДІЯЛЬНОСТІ}

\author{
Стукан Г. О. \\ кандидат педагогічних наук, \\ доцент кафедри української мови та літератури \\ Хмельницька гуманітарно-педагогічна академія \\ Крищук В. Л. \\ кандидат філологічних наук, \\ дочент кафедри украӥнської мови та літератури \\ Хмельницька гуманітарно-педагогічна академія \\ Глушок Л. М. \\ кандидат педагогічних наук, \\ доиент кафедри іноземних мов \\ Хмельницька гуманітарно-педагогічна академія \\ м. Хмельницький, Україна
}

Результатом наукової підготовки здобувачів другого (магістерського) рівня вищої освіти є виконання і захист дипломної роботи, яка повинна містити наукове обгрунтування теоретичних чи експериментальних результатів, висновків та рекомендацій і засвідчити спроможність майбутнього вчителя $33 \mathrm{CO}$ чи викладача $3 \mathrm{BO}$ самостійно проводити наукові дослідження в обраній галузі наук.

У процесі опанування навчальними дисциплінами випускникимагістри навчаються орієнтуватися в особливостях використання інноваційних психолого-педагогічних концепцій, мовознавчих та 
літературознавчих досягнень, методик розв’язання науководослідницьких завдань.

Дуже важливим етапом для здобувачів $\epsilon$ науково-дослідницька практика, під час якої магістранти проводять наукові дослідження, необхідні для написання дипломної роботи. Усвідомлення об'єкта дослідження вимагає від студента вивчення та аналізу теоретичних положень, сформульованих у наявній літературі в аспекті дослідження проблеми та формулювання чітких висновків, які у другому розділі будуть ілюструватись доцільними прикладами, результатами експерименту, доповнюватись, підтверджуватись чи заперечуватись.

За бажанням здобувачі обирають одну із літературознавчих, мовознавчих чи методичних тем. Списки тем пропонують викладачі, проте здобувач може запропонувати іншу, яка його цікавить більше. Для літературознавчого аналізу, як правило, обираються художні твори, які вивчаються у школі, а для аналізу зображувально-виражальних засобів лексичного, фонетичного, морфологічного, синтаксичного рівнів бажано обирати найновіші художні твори, які мало або й зовсім не досліджувались.

Методичні теми присвячуються формуванню практичних умінь i навичок, зокрема комунікативних умінь і навичок школярів, застосуванню інтерактивних прийомів та вправ (асоціативний кущ, ментальна карта, фішбоун, мозковий штурм, мікрофон, ажурна пилка, РАФТ, метод кейсів, ротаційні трійки, метод «прес», займи позицію, щоденні 5), проєктному та проблемному навчанню, формуванню навичок роботи у групах, аналізу підручників та посібників тощо. Саме за таких умов здобувач зможе довести актуальність предмета дослідження та виявити самостійність.

Важливість отриманих результатів обов'язково апробується на конференціях, семінарах, обговорюється на засіданнях кафедри, публікуються тези та статті у наукових збірниках. Магістрів слід залучати до міжнародних та всеукраїнських конференцій, які проводяться іншими закладами. Так, у Хмельницькій гуманітарнопедагогічній академії вже на першому році навчання окремі здобувачі мають по 6-8 публікацій $[2 ; 3 ; 4 ; 5], 3$ успіхом виступають на міжнародних та всеукраїнських конференціях, беруть участь і займають призові місця у конкурсах наукових робіт, проходять онлайн-курси та беруть участь у вебінарах (студія онлайн-освіти EdEra, Prometheus, український освітній онлайн-портал «На урок», Всеосвіта, онлайнплатформа компанії «Лінгвіст» тощо). Магістри очолюють студентське наукове товариство, організовують його активну роботу, редагують видання студентів та слухачів магістратури «Науковий вісник». 
Свої наукові статті магістри також публікують у збірнику «Філологічні студії», який видається щорічно 32014 року за матеріалами дипломних робіт.

Підготовці тез та наукових статей передує така робота: науковий керівник ознайомлюе з вимогами до написання малих за обсягом студентських наукових праць, разом 3 ними аналізує окремі зі студентських збірників, а потім пропонує кожному проаналізувати студентську публікацію самостійно за схемою: назва статті, автор, збірник, рік видання; інформативність анотації; точність ключових слів; актуальність обраної теми, обгрунтування ії у пункті постановка проблеми; формулювання мети, визначення предмета дослідження; аналіз праць з досліджуваної проблеми, логічність зроблених висновків; виклад основного матеріалу (теоретичне обгрунтування, підтвердження прикладами, фактами, цифрами тощо, їх доцільність); формулювання висновку (точність, відповідність поставленій меті); яку літературу використано, як оформлено.

У результаті студенти розуміють важливість основної частини статті, вчаться висвітлювати теоретичні положення і результати дослідження, формулювати власні думки та висновки визначати теоретичне та практичне значення.

Важливо, щоб студенти дотримувалися норм цитування, поважали інтелектуальну працю інших, яка захищена законодавством України (Конституція України, Закони «Про авторське право і суміжні права», «Про наукову і науково-технічну діяльність», «Про вищу освіту»).

У Методичних рекомендаціях для закладів вищої освіти з підтримки принципів академічної доброчесності зазначається, що для якісного академічного письма студенти мають опанувати такі знання й навички: шукати, обирати й оцінювати якість джерел; робити нотатки, завжди вказуючи джерело; виділяти головні думки в тексті; підсумовувати текст та ідеї; перефразовувати чужі думки своїми словами стисло, детально, без зміни змісту цих думок; правильно описувати посилання на джерело; правильно цитувати; знати про форми академічного плагіату і про шляхи запобігання йому; формулювати і чітко висловлювати власні думки; знати структуру академічного тексту; вміти виокремити текст цитат у власному тексті [1, с. 4-5].

Магістри брали участь у вебінарі «Курсова робота без академічного плагіату - нові можливості системи StrikePlagiarism.com» $(19.04 .2021$ р.), з якого дізналися багато корисного щодо написання та впорядкування наукових робіт, практично побачили, як перевіряється текст на унікальність та встановлюється наявність запозичень. 
Поряд 3 цим практиканти надають консультації студентам другого і третього курсів до написання курсових робіт, вчать оформляти літературу відповідно до вимог, правильно послуговуватись цитатами, формулювати висновки до розділів та підрозділів, часто бувають присутні на захистах. Очевидно, що такі навички допоможуть майбутнім учителям успішно керувати написанням наукових робіт школярами на конкурс МАН, структура яких багато в чому подібна до структури та обсягу курсових робіт.

У період науково-дослідницької практики здобувачі першого року навчання організовують проведення науково-методичних семінарів спільно зі студентами першого (бакалаврського) рівня вищої освіти, залучають їх до виступів та обговорюють важливі методичні проблеми.

По закінченню практики здобувачі звітують на засіданні кафедри. Інформацію про проведені види роботи студенти подають на сайт академії.

Уже кілька років поспіль головами державних комісій є наші стейкхолдери, учителі базових шкіл, які дають детальний аналіз готовності до навчально-виховної та науково-дослідницької роботи майбутніх учителів, висловлюють свої пропозиції.

Варто зазначити, що студенти мають тісний зв'язок з учителями шкіл, які допомагають проводити анкетування, бесіди, опитування, перевіряють доцільність використання запропонованих студентами інтерактивних вправ тощо, а також пишуть у співавторстві зі студентами науково-методичні статті.

Таким чином, підготовка магістра педагогічної освіти здійснюється за навчальним планом та освітньою програмою, які забезпечують сучасний рівень кваліфікаційної підготовки. Вони спрямовані на формування особистості, яка здатна на професійному рівні вирішувати освітні i виховні завдання, здійснювати науково-дослідницьку роботу в умовах формування національної системи освіти, виводять їі на рівень міжнародних критеріїв і стандартів.

\section{Література:}

1. Методичні рекомендації для закладів вищої освіти з підтримки принципів академічної доброчесності. URL: https://mon.gov.ua/storage/ app/media/vishcha-osvita/2018/10/25/recomendatsii.pdf (дата звернення 01.07.2021).

2. Долгова Юлія. Особливості використання евфемізмів у сучасному медіатексті. Актуальні проблеми сучасної філологї та культурології: постмодерністська парадигма: матеріали VII Міжнародної 
науково-практичної конференції (Хмельницький, 15 травня 2019 р). Хмельницький: ХГПА, 2019. С. 137-143.

3. Філь Анастасія. Мовний аспект концептів життя-смерть у збірці «Палімпсести» Василя Стуса. Загальна та прикладна лінгвістика y колі антропоцентричних наук: матеріали Всеукраїнської науковопрактичної конференції студентів та молодих учених (м. Миколаїв, 2 квітня 2021 р.). Миколаїв: СПД Румянцева Г. В., 2021. С. 131-135.

4. Філь Анастасія. Дослідження функцій неповних речень у романі Івана Багряного. Науковий вісник. Хмельницький: ХГПА. 2020. Вип. 2. С. 7-10.

5. Шершун Уляна. Сучасні підходи до формування лексичної компетентності на уроках української мови. Філологічні студії: збірник наукових статей слухачів магістратури спеціальності 014 Середня освіта (Українська мова і література) за матеріалами дипломних робітна здобуття другого (магістерського) рівня вищої освіти. Хмельницький: Вид-во ХГПА, 2020. С. 86-89.

DOI https://doi.org/10.30525/978-9934-26-114-5-63

\title{
ПЕРСПЕКТИВИ ВИКОРИСТАННЯ ДОСВІДУ ПІДГОТОВКИ МАЙБУТНІХ УЧИТЕЛІВ ДО НАДАННЯ ФАСИЛІТАТИВНОЇ ПЕДАГОГІЧНОЇ ПІДТРИМКИ СІМЕЙ У НОРВЕГІЇ
}

\author{
Трухан $\Gamma$. В. \\ аспірант кафедри освітології та інноваційної педагогіки \\ Харківський начіональний педагогічний університет \\ імені Г. С. Сковороди \\ м. Харків, Украӥна
}

Переживаючи демократичні перетворення, українське суспільство звертається до пошуку раціональних шляхів формування особистості нової фундації, яка володіє компетентностями, необхідними для успішної реалізації в світовому суспільстві. Умови, що створюються громадою для розвитку дитини в освітніх установах системи, $\epsilon$ визначальним фактором формування іï особистісних якостей і можливостей. Процес модернізації освіти передбачає створення системи, що відповідає викликам сучасності, де педагог виступає фасилітатором навчального процесу. Слід зазначити, що ефективність процесів перетворення галузі освіти може бути забезпечено за умови створення 